\title{
Memory, Politics AND the CONSTRUCtion OF A NATION'S IDENTITY. INTERNMENT CAMP FOR WOMEN (ALZHIR) NEAR ASTANA (KAZAKHSTAN)
}

\section{Ewa Nowicka*}

\begin{abstract}
The article analyses the contents of the Museum and Memorial Complex of Political Repressions and Totalitarianism Victims on the former Akmolinsky Camp for Wives of the Traitors of the Motherland (Akmolińskij łagierżon izmiennikow Rodiny, ALZhiR). The author describes and scrutinizes the functioning of the museum "ALZhIR" in the context of internal and external politics of the Kazakhstan state conducted by president Nursultan Nazarbayev and his allies. The museum not only introduces the camp reality but also highlights the support given to the Kazakh state and Kazakh nation. The author focuses on the analysis of those aspects of the museum content that present the national ideology, which main ideas are a glorification of Kazakh history, culture and humanitarianism (i.e. fundamental requirement of giving aid to the people in need).
\end{abstract}

Keywords: museum "ALZhIR", Kazakhstan, nation building, glorification of national history

Creating the English-language version of the journal "Zoon Politikon" is financed under contract No. 724/P-DUN/2018 from the funds allocated by the Minister of Science and Higher Education for dissemination of science.

*Professor Ewa Nowicka, Collegium Civitas, Warsaw, Poland, e-mail: ewa.nowicka@civitas.edu.pl ORCID: https://orcid.org/ 0000-0003-0170-0845 


\section{Introduction}

In recent years, there has been a significant increase in reflection on the forms of narrations and memory discourses in social sciences, and sociology of memory is currently an important part of thought on the society.

Scientific reflection focuses on cultural messages that are visible in the content conveyed by various types of institutional activities, including museums. On the one hand, the interest of researchers concentrates on the ways of building social memory through the presentation of the museum content, on the other on the construction of a new, though at the same time rooted in social forms of thinking, meaningful structures and symbolic constructions. The sociological, historical and anthropological literature on the topic of memory is exceptionally extensive and multithreaded.

In Polish literature, the issue of memory construction in various fields of culture is dealt with by growing number of sociologists among which one should mention the precursor of research on the functioning of historical knowledge in the present - Nina Assorodobraj, the author of the famous article Living History (1963); as well as Barbara Szacka, Andrzej Szpociński, Piotr Kwiatkowski; and in recent years: Zuzanna Bogumił (who gives attention to the analysis of the contents of museums), Małgorzata Głowacka-Grajper, J oanna Wawrzyniak, Magdalena Saryusz-Wolska (it is impossible to name all researchers, so I apologize for the omissions). In addition, many scholars include in their work the problem of memory in the background or marginal). The work of all these scholars introduces into the sociological literature in Poland the concept of collective and cultural memory and the idea of historical policy.

My intention was an analysis which to some extent deviates from interests of authors mentioned above including Zuzanna Bogumil, who scrupulously analyses thememory of repression period in the European 
part of contemporary Russia (2012). My aim was to depict identity policy of Kazakhstan leaders by an analysis of one specific museum project, which, by an assumption is dedicated to Soviet crimes, yet is noticeably different in comparison to museums of this kind in the Russian Federation. This specificity makes my interests and narration of analysis deviate from other studies in the field of research on social memory.

The subject of the study, which I carried out in July $2016^{1}$ in Kazakhstan was a museum commemorating Akmol Labour Camp for Wives of the Traitors of the Motherland (ALZHIR). It was one of the many Soviet camps established at the time when the present territory of Kazakhstan belonged to the USSR. However, it was different from the others because only women were kept there, except for their small children. To commemorate the camp, the authorities of independent Kazakhstan created a museum of women victims of repression near Astana. It is not a coincidence that the museum was established in the period following the dissolution of the Union of Soviet Socialist Republics, more than a dozen years after Kazakhstan's independence. It was open on the initiative of the President of the Republic of Kazakhstan, Nursultan Nazarbayev on May 31, 2007.

The article is devoted to the role played by ALZHIR in internal and external policy of Kazakhstan ${ }^{2}$, led by President Nursultan Nazarbayev and his team. Nazarabayev - a key figure in an independent state - is important for providing the museum of the camp for women near Astana the sense of an object of national and state value. There was not a close relationship between the camp for women and the Kazakh ethnos, but now, the museum devoted to it is inherent in the policy of

1 I would like to thank the Kazakh scholar Assylkhanov Bikenov for cooperation during my stay in Kazakhstan, where I stayed in June and July 2016 at the invitation of the L.N. Gumilyov Euroasian National University in Astana.

2 In this article I omit interest in ALZHIR, present in contemporary pop culture of the Russian Federation, such as A.L.Z.H.I.R., a 2018 Russian television series devoted to the victims of the camp, directed by Alexander Kasatkin. 
the Kazakhisation of the state primarily through various, apologetic forms showing the Kazakh nation. The policy of the long-term president of the independent Republic of Kazakhstan is aimed at constructing a modern Kazakh nation through, among others, language Kazakhization of the society, and apologia for the past of Kazakh people (see Chebotarev 2015). A characteristic feature of this policy is its officially undeclared and even concealed character - the Kazakh authorities are denying the existence of a policy of strengthening the sense of national pride and dominant position of the nation in the state. However, for an external researcher, the policy of rebirth and strengthening the Kazakh language, Kazakh culture, an awareness of the history of the Kazakh nation, including its outstanding heroes, and moments of glory, is noticeable at every step (Sejdimbek 2012).

An instilment of these contents takes place simultaneously with an emphasis on the principles of internationalism, the principles of friendship among nations living in Kazakhstan. Kazakhstan, according to the discourse, is a state in principle multinational, in which the cooperation and tolerance prevail (Karin, Chebotarev 2002). One of the stages of the past of Kazakhstan is the period of the Stalinist regime and the existence of the ALZHIR camp. Linking the topic of Kazakhstan's national policy with the commemoration of victims of repression through a museum may seem not only unobvious but even controversial.

This article is to prove that the relationship between these two facts is not absurd and unbelievable. The analysis of the content provided in the ALZHIR museum stresses the basic trends in the national/ ethnic policy of the elites of modern Kazakhstan. This will become clear when the complex of contents and invoked associations within the museum is presented. In addition, the threads to which the persons accompanying the researcher (author of this text) refer when visiting 
the museum, as well as the information and content that can be found on the museum's website.

A study of collective memory

By analyzing a specific case of a museum, I accept some more general assumptions and present a study that falls within the scope of memory studies. Questions about collective memory provoke the discussion about the mechanisms of shaping different representations of the past and present of social groups. The mechanism for the selection of facts, events, characters included in the current discourse becomes an important issue. The construction of social memory is closely related to the process of creating a collective identity, including primarily a national one. The case of the discussed museum indicates the importance the images of the past have for the present. I treat the museum as an institution which, in principle, constructs the threads of collective memory relevant to a given society, by the presentation of content that influences the imagination of visitors, arouses emotions and is oriented towards the transmission of specific values. A museum usually provides an interpretation of specific fragments of the past, always possessing a certain information layer, provides specialist information, but is also referring to colloquial ideas that ensure the communicativeness of the given content. Therefore, from the point of view of the researcher of social life, a museum is, first of all, a material for observing contemporary society, ideological tendencies, political discourses currently present in society (see Bachórz 2009).

The content provided by the museum reaches a huge number of diverse recipients thanks to its comprehensible, concise and attractive form. There is always easy-to-receive content, adapted to the popular form of communication. In order to be communicative and persuasive, the museum must adapt to the system of meanings, concepts, 
axiological content, understandable, attractive and known to the society to which the message is to be transmitted. The analysis of the conveyed content and attitudes formed by museum exhibitions is a part of a broad field of research on collective memory, to which a huge, ever-growing literature is dedicated (see Głowacka-Grajper 2016; Bogumil, Wawrzyniak 2010). The next stages of the analysis contained in the article will present the basic elements of the Kazakhstan state's political situation, its internal and external threats, a detailed description of the camp museum structure and its performative meaning that builds the idea of community, historical size and power of the Kazakh nation. The ALZHIR museum is - in my interpretation - an element of the policy of building a unified state based on a cultural community (see Gellner 1992, p. 75). Elements of this policy are: establishing a cultural canon, building museums, constructing the officially accepted version of history, formulating new school programs (Edensor 2004, p. 15).

The history of the camp

Under the decision of Matvei Berman (head of the communist Main Administration of Camps - GULag, in the period from 9 J une 1932 to 16 August 1937), taken in J uly 1937, as part of the beginning of terror throughout Soviet Union, the Akmol Labour Camp for Wives of Traitors of the Motherland (ALZHIR), as a "correctional labour camp P-17", intended for women and children of "repressed" families (murdered). On August 15, 1937, NKVD issued an order no. 00486, which gave the right to arrest and sent to the camps family members of motherland traitors, without proof of guilt. In the first place, it was about wives, sisters, and mothers of the political prisoners. Within a few months, women were sentenced to 5-8 years of the camp, which was a “correctional labour camp". Its construction was completed in 1938.

The camp was closed in 1953 and completely liquidated in 1959. 
Apart from women — not only as the official name sought, wives there were also sisters, mothers, and further relatives of the repressed men, referred to as traitors of the motherland, the camp also included their small children, both those born earlier and already in the camp. Until the age of three, they remained in the camp with their mothers, then they were taken to the orphanages. Sometimes their origin was completely erased, names and birth documents were changed. Prisoners were often women from families of communist party activists, defendants, convicted persons, serving their sentence in prison camps, or already murdered.

The social composition of prisoners is noteworthy: $90 \%$ of them were people with higher education. There were female artists, academics, and people performing jobs requiring exceptionally high qualifications. There were women of sixty nationalities in the camp. Among them, there were 88 Kazakhs, who were from the families of Alash nationalist party (http://www.museum-alzhir.kz). Among the prisoners, the majority were Russians - 4339 and Ukrainians - 739. There were also 173 Poles, who were accused of counter-revolutionary, pro-bourgeois, and anti-state activities. They came mainly from the pre-war parts of eastern Poland, which were occupied by the USSR in September 1939 and after the Second World War, they did not further belong to the Polish state. 169 Germans also arrived at the camp, recruiting mainly from former settlers. Until now, no reliable statistics have been established on the number of people who died in the camp, who survived or who died shortly after leaving the camp3.

3 On the ALZHIR museum website one can find accurate statistics divided by the nationality of female prisoners with the possibility to read their names and the number, date of the sentence and the date of leaving the camp or death. There is also presented an extensive in number photo documentation of people, clothes and objects used in the camp. 
The museum is constructed entirely "from scratch" because there is nothing left of the barracks - neither the infrastructure nor the objects used by the prisoners. It should be remembered that the camp operated from 1938 to 1953, and 60 years have passed since the camp was completely dissolved and when the museum was opened. The museum is a well-thought-out and structured exposition with less intention to show documentation, preserved real objects remaining after the prisoners, but with a view to obtain a specific impression on the visitors. The ALZHIR Museum has the intended structure: it is divided into external and internal part. The external part is available to a visitor without entering the main building, circling the open area. The internal part is located in a two-storey central building.

A description of the external part is to be noticed by the visitors entering the main building, which is a tower referring to the camp building. Currently, it houses a historical museum. A huge, openwork monument rises in front of the tower, in the shape of a high oval with a top made of a lattice. Horizontal mirrors are placed in the upper part of the building. Inside the arch, there is an inscription in English (Arch of Sorrow) and: "Bend your head to pay homage to the victims of political crimes". On the left, on the platform, an original freight wagon is presented, one of which the prisoners were brought to. In front of the building of the proper museum, on the left and right side from the main axis, there are eight obelisks dedicated to various nationalities of prisoners - the first from the left, from red granite, is devoted to the Poles staying in the camp (it was unveiled in 2010).

On both sides of the memorial, thereare two bronze figures depicting a woman and a man, symbolizing two attitudes towards violence and suffering. A man with facial expression and body posture represents desperation and submission to inevitable fate, despair and apathy. 
A female figure with a book in her hand presents an attitude of hope and duration despite all the suffering and adversities. At the bottom of the figure, there is an inscription in three languages (English, Russian and Kazakh): "War and hope". At the back of the museum building/ tower, there is an arched wall of black marble with a few thousand names of victims, placed alphabetically.

One of the stories repeating like a mantra (obsessively) during the visit to the museum is a story about the help of prisoners from the surrounding Kazakh population. Children and Kazakh youth threw "stones" at women. The frightened prisoners after some time discovered that the alleged stones are pieces of Kurd, traditionally dried cheese, having great nutritional value, essential for biological survival in the extreme conditions of the camp. This story returns in private conversations and, with many details and comments, on the museum's website.

The internal part of the museum

The building houses the internal part of the museum. It has the character of a museum exhibition in the strict sense of the word. The "true", in the words of Kazakh scientists, the history of Kazakhstan, the periods of magnificence of the Kazakh nation, methods of fighting for independence from Russian violence - the next stages and attempts to achieve liberation from foreign domination - are presented here. The whole exhibition is permeated by one subject: determination in successive periods of the armed and diplomatic struggle of the Kazakhs for independence, lasting from the 18th century. It is interesting to discuss not only what is shown at the exhibition, but also what is not there; it is about historic data that is silenced or bypassed. The latter includes both the elements of the gradually liberalizing tsarist policy and the early policy of the twenties of the twentieth century when the 
communist authorities adopted the principle of "korenizatsiya" [principle of rooting] — including the indigenous ethnic population in the local administration. This period was important for shaping the modern national feeling among the Kazakhs (Masanov 2002).

The exhibition shows the ruthlessness of tsarist Russia's power, the process crowned by the liquidation in 1823 and the division of the former state of Khans into districts. It shows the violence perpetrated on them by the ever more numerous troops of Russian Cossacks whose invasion of ethnically Kazakh areas began at the end of the 18th century when the first fortresses were built. Attention should be paid to the terminology used in the exhibition. It is said that "colonial power went so far" - the texts posted on individual museum tables use this term. It is written about the colonial status of the territories and people of present-day Kazakhstan in the 19th century. At the same time, the active resistance of the Kazakh society - outstanding characters crucial for the Kazakhs' independence movement - is presented. One of them is Kenesary Kasymov, entitled "khan" (1802-1847), the initiator of the national liberation movement in Kazakhstan in 1837-1847.

The exhibition underlines some typical measures for the colonial power of the Russian empire: "it gave the best agricultural lands to the Cossack settlers". We find detailed information on the density and strength of colonial settlement. The second stage in taking the Kazakhs their country was the subsequent massive agricultural colonization on a large scale - resettling peasants from Russia and Ukraine to areas considered empty. According to the information for visitors, the census of 1897 shows that over half a million Russian and Ukrainian displaced persons already lived in Kazakhstan. This information, given to visitors, including the Kazakhs, shows where so many of the Slavic inhabitants of northern Kazakhstan came from, realizing at the sametime that these areas are indigenously Kazakh. In a part of the exhibition, there are 
documents indicating the activity of Kazakh leaders who at various historical moments demanded a just solution to agrarian matters.

The second stage of the struggle for the rights of the Kazakh nation begins at the turn of the 19th and 20th centuries. The process of shaping the organized national liberation movement took place. The process dates back to the time of practical suppression of the Kazakh khan in the first half of the 19th century. Elections to Duma in tsarist Russia caused an increase in political and ethnic awareness and activity among Kazakhs. At first, 13 delegates were chosen to Duma: 4 Kazakhs, 9 Russians, among the Kazakhs there were democratic and national directions of political orientation; Kazakh newspapers and periodicals were created. The marginal exhibition mentions that the publishing movement developed during the period of increased political activity throughout Russia just before the outbreak of the First World War and that the process concerned not only Kazakhstan.

The exhibition presents outstanding figures of 20th-century intellectuals and activists such as Bukeikhanov - a Kazakh scholar, economist, and activist of the democratic-liberal movement. The next stages of the struggle for breaking with the domination of former Tsarist Russia, then the Soviet one, are shown. The events are presented on J uly 20-21, 1917, when the congress of all Kyrgyz peoples was held (the Kazakhs were also so-called). It was a formative act for the political separateness of Kazakhstan. At that time, the legal principles of the republic were established, the scope of Kazakh districts, problems of land ownership, a regional militia, education system, judiciary were established, and religious and women's rights issues were also addressed.

The aforementioned political party Alash, consisting of Kazakh intelligentsia educated abroad and in Russia, was established at the congress, the aim of which was to obtain broad autonomy, and then regain independence. In the 1930s, the organization was persecuted by 
the Soviet authorities. Women related to the activists of this movement were sent to the ALZHIR camp. It is emphasized that the party Alash rejected one of the operational assumptions of the revolution - violence, the humiliation of nations "expressed in the dictatorship of power". Alash activists disagreed with the principles of totalitarianism, unifying ideology, destroying the tradition, culture and achievements of nations. "The fact that outstanding and unique personalities were annihilated during the repression is the stigma of Bolshevism. It is a tragedy that we will not forget after a century". They "created the power of the new republic", established after the October Revolution. Among the members of Alash, Mustafa Shokay is distinguished. He played a key role in the creation of Turkmen autonomy and created the foundations of the community of Turkic-speaking peoples.

Only the second floor of the museum is dedicated to the ALZHIR camp itself. There are exhibited images of how prisoners could live rather than documents. The English-speaking tourist receives the aforementioned story of the Kazakh youth, throwing prisoners dried cheese, thanks to which some women survived ${ }^{4}$. The inner part of the museum ends with a film depicting the realities of the camp, the living conditions in it, as well as reports about the merits of its builders. At the end of the film, there is a speech by President Nursultan Nazarbayev, in which there is a great accusation of the Soviet Union authorities to introduce and organize persecution, which led to the death large numbers of children and infants in the ALZHIR camp. In Nazarbayev's speech at the exhibition, we hear: "innocent, killed without any reason by their own state! Hitler killed aliens - of course, this is barbarism he killed J ews, Russians, the Soviet people - those he fought with. Our authorities, on the other hand, killed its own nation. There is no other similar examplein the history of mankind. Their fault was only that they

4 The atmosphere surrounding the museum among the Kazakh intelligentsia is greatly explained by the fact that the Kazakh scientist accompanying me in visiting the museum expresses deep satisfaction that the Polish anthropologist devotes so much time to reading this "real history of Kazakhstan". 
honestly and conscientiously served the regime in which they lived. 40 million repressed in the former USSR! 3.5 million only on the basis of Article 58, as counter-revolutionaries and enemies of the people! And their children, their relatives got to know all the bitterness of misery and persecution".

This accusation is directed to authorities presented as foreign, which have nothing to do with today's Kazakhstan (where a unique museum was built - not in the Russian Federation). The cut-off from the past for the leader is closely related to his concept of building a single, strong, independent nation and state.

The museum website

The scope of information available on the website dedicated to the ALZHIR museum deserves analysis, among other things, due to the extent of the medium's influence, mainly among young and youngest recipients. Some information is identical to those available at the exhibition, while others expand some areas. We also find extensive information on the topics of the ALZHIR camp itself, strictly unconnected, about other persecution of national groups in the period of repression, in later years and during the entire period of Soviet regime. Weread the following information: "The deportation exhibition shows mass political repression against entire nations. Over 1.3 million people were deported to Kazakhstan; Germans, Turks, Koreans, Poles, Chechens, Crimean Tatars have been subject to forced resettlement".

It is significant that in this enumeration of resettled nations there are no Russians, who - as we know otherwise - were the most numerous among persecuted and deported". Wealso read: "Documents have been fabricated in Moscow and in Leningrad, which has become the basis for the persecution of the national intelligentsia”. A non-existent state is 
accused of which Kazakhstan managed to free itself from the moment it crumbled as a political structure.

The same narrative contains important historical information, close to the moment of the establishment of an independent state of Kazakhstan. It's about the "December events. On December 16, 1986, students and working youths, who believed in the process of democratization, went to the Alma-Ata squares to protest. Moscow officially assessed these events as a manifestation of nationalism. During the December events, several people were killed, many were injured, 99 people received different sentences, and 19-year-old K. Ryskułbiekow was sentenced to be shot".

At the end of the text posted on the museum's website, we find a statement that "a shared memory of shared times is the basis on which the agreement between nations is built". Next, we find a lot of materials devoted to the generous help of the Kazakh nation to persecuted people. A well-presented, already well-known and on every occasion repeated story about the Kazakhs, who threw the dried-up cheese at the prisoners. This is how a narrative about the nobility and ingenuity of the Kazakh nation arises.

In connection with the descriptions of the ALZHIR Museum, a film made by a Kazakh about the noble acts of the Kazakh nation, depicting a traditional Kazakh family with grandfather, parents, children and an inseparable horse, appears on YouTube. The film is accompanied by the commentary of the film's author and the initiator of showing it to a wider audience: "How the Kazakhs saved the lives of the repressed wives". The author continues: "The film is based on real events".

There are also fragments of a prisoner's diary, Gertruda Płatais, which tells the whole story of the history of the Kazakh people's help in detail. We also read the statements of people of Korean nationality, especially those experienced during the period of repression. 
A young Korean named Coj writes: "We - deported nations succeeded that we just got to Kazakhstan. Many people survived thanks to such a good, sincere and noble nation. Kazakhs, be proud of yourself! Be like your ancestors!". Another Korean, son of a deported family, also mentions the help of the Kazakhs during dramatic times. "If it were not for the Kazakhs, today there would be no me and many others". Among the thanks and comments one is written by a person with a Russian name and surname, signing as "Daria from Russia": "I have a sense of gratitude for preserving the memory of the Kazakh people who during hard years saved lives of people of other nations".

On the Internet you can find many short films in the same tone, showing the help of Kazakhs for people of different nationalities in the most difficult times of persecution and starvation. In the comments we find a glorifying description of the further development of the political situation: "then the same Kazakhs built a joint multinational state, based on peace and mutual understanding". The role of ethnic Kazakhs in this narrative about building independent Kazakhstan is defined as key and leading. At the same time, one can read in it the tone of ethnic paternalism. The website repeats the declaration of the uniqueness of such an institution in the entire post-Soviet area, present in the content conveyed in the museum ALZHIR and in conversations with the Kazakh intelligentsia. It is pointed out that numerous camps in West Siberia and Mordwa for families - wives and children of the enemies of the regime - have never been commemorated. Only in Kazakhstan, near the capital of the country, a museum commemorating ALZHIR was built.

The nation-creating sense of the museum

I return to the thesis at the beginning of the article about the relation between the ALZHIR museum and the current policy of the Kazakh authorities, including in particular the president. Observing sometimes 
surprising components of the museum, the researcher is looking for the sense of linking all the elements of the vision built around the museum near Astana. Interpretation is imposed on the terms of constructing a new state. The essence of the museum of repression of women seventy years ago is, according to this interpretation, on the one hand constructing the ideology of the Kazakh nation and an independent nation-state, and on the other ostentatious emphasizing independence from the Russian Federation.

In order to understand the motivation behind setting up a camp museum and the content that it obsessively communicates to visitors, one must resort to the political context in which Kazakhstan was formed and developed as an independent state. The ALZHIR Museum is part of the general tone of the historical and cultural policy of the Kazakh state. The beginnings of an independent state are marked by many political moves, including the construction of its own image of the Kazakh people, its history, culture and values, that it brings to the treasury of humanity. The political elite of independent Kazakhstan is dominated by motives related to the project of building and strengthening the national ties, ethnic and historical pride of the dominant titular nation.

Among the other things, a number of state holidays were established as a part of the re-traditionalization policy. They have restored Naurys, the Zoroastrian New Year related to the pre-Muslim tradition, falling on the spring equinox on March 21-22. It is celebrated in a large area of Central Asia (Penkala-Gawęcka 2009). The author places the regeneration of the holiday on the policy of the developing national state and its intricate meanders. The context that allows understanding these actions is the situation of Kazakhstan, both internal and external. We find within it various types of threats to the whole of independent Kazakhstan, which political leadership must face. 
Political context: threats and problems

The independence of the Republic of Kazakhstan was announced on December 16, 1991, which was really the beginning of the process, not its end. An independent state had to face many problems. Its area covers a large area - 2724900 square kilometers, thus Kazakhstan is the third in terms of territory in Asia and the ninth country in the world. It occupies almost $2 \%$ of the globe and $6.1 \%$ of the territory of Asia.

It is also the second-largest post-Soviet state created after the collapse of the Soviet Union. It occupies a central place on the Eurasian continent: the center of Eurasia is located in the eastern part of Kazakhstan. The internal policy of the country is determined to a large extent by geopolitical conditions. In total, the length of all Kazakhstan's borders with neighbours is $12,187 \mathrm{~km}$, including primarily with the Russian Federation $(6,467 \mathrm{~km})$, China $(1,460 \mathrm{~km})$ and Uzbekistan $(2,300 \mathrm{~km})$, as well as with Kyrgyzstan $(980 \mathrm{~km})$ and Turkmenistan (380 km).

As a nation, Kazakhs have had hundreds of years of contact with the tsarist Russian empire, then for seven decades, Kazakhstan was a part of the USSR. The length of the border with Russia means that relations with this world power are delicate and require subtle diplomacy. Relations with the Russian Federation and the People's Republic of China can be justifiably perceived as areas of external threat. In addition, Kazakhstan is an area rich in natural resources that attract the attention of various countries, including neighbours (see Kazachstan. Społeczeństwo, historia, polityka 2000), and for a long time for the USSR Kazakhstan was a source of raw materials and agricultural products (Wites 2002).

After declaring independence, the leadership of the Republic of Kazakhstan has had many tasks, including the establishment of the legal order, administrative divisions, organization of social and cultural 
life (Bisztyga 2015). Decisions in this area had to take into account the size, shape, past, neighbourhood and ethnic composition of the newly created state.

Among the internal threats, the multinational structure of an independent country is the most important. The population of Kazakhstan is 17733198 people (as of 1 April 2016) and its ethnic and cultural diversity is enormous. The structure of this diversity is important; although in the public discourse it is said that there are 121 different nationalities in Kazakhstan, in fact, the core is Kazakhs and Slavic people (mainly Russians). The state is inhabited by $66.48 \%$ ethnic Kazakhs, $10.61 \%$ of Russians and $12.91 \%$ of people of other nationalities. At the same time, it should be remembered that in the 1990s, the percentage of the Kazakh population did not reach half of the population. According to data from 2014, the "other" nations include Uzbeks (3\% of the total population), Ukrainians (1.8\%), Uygurs (1.4\%), Tatars (1.2\%) Germans (1.1\%). These territorial and population conditions provide the Kazakh authorities with problems to solve.

\section{Decolonization}

These problems are sometimes referred to in scientific reflection as the fight for the decolonization of Kazakhstan. Western scholars, including Polish, refer to the intellectual current as part of the reflection of social sciences on contemporary social processes in the world using the terms colonialism, postcolonialism and decolonization (Thompson 2000). The category of "decolonization" is, in my opinion, a good tool to explain the current cultural and historical narrative in Kazakhstan, constituting a basic challenge for the Kazakh authorities. This complex procedure must take various forms, among which the creation of a new historical narrative, including the erection of the ALZHIR camp museum, occupies an important place. One of the forms of this activity is the 
glorification of Kazakhstan and the Kazakh nation. Another of the decolonization activities is the impact on the move away from identification from the empire of the Soviet Union and the building of a new political Kazakh identity.

In the thinking of all nations, which until 1991 belonged to the Union of Soviet Socialist Republics, the Soviet identity in the social consciousness lasted for a long time (Thompson 2000). As Piotr Załęcki writes, using statistical material, a departure from the identity of the Soviet community and building it at the expense of the national consciousness of the newly formed countries after the collapse of the USSR, followed gradually. The research conducted by VCIOM (Russian Public Opinion Research Center) in 1991 and 1993 may be helpful in this regard. In 1991, Russians, Ukrainians and Kazakhs were seen as citizens of the USSR (63\% of Russians in Russia, $42 \%$ of Ukrainians and $48 \%$ of Kazakhs). Such self-identification, however, did not appear at all in the representatives of the nations of the former Baltic republics, which at that time experienced a renaissance of their statehood and an increase in national self-awareness. Only two years after the collapse of the USSR, more than a quarter (26\%) of ethnic Kazakhs identified themselves as citizens of the Soviet Union.

In the context of these facts, the nationalistic aspirations of the elite centered around Nursultan Nazarbayev acquire a profound meaning in the newly-created independent state, in which the titular nation is indeed a numerical majority, but not an overwhelming majority. In addition, it must not be forgotten that apart from obvious reasons of difficult relations with the Russian Federation, Kazakhstan has enemies among other nations, including newly-established states such as Kyrgyzstan, which has territorial claims against Kazakhstan. Colponbaj T. Nusupov, a Kyrgyz professor who curses Kyrgyz, who voted in favor of putting part of the lands to Kazakhstan in the following way: "Let your family and offspring cease to exist, let the spirits of your ancestors, 
the ghosts of great-grandfather Manas and Kosoja, rulers-heroes punish you" (Załęski 2012, p. 97-98).

Tolerance and multiethnicity

The multi-ethnic character of the state is treated as a great value in the public discourse. At every step, the multi-ethnic character of Kazakhstan's society can be highlighted, mutual tolerance, peaceful and friendly relations among 121 nations inhabiting Kazakhstan are emphasized. The state narrative stresses the uniqueness of Kazakhstan; exaggerates the state of multiethnicity of the country, pointing to the uniqueness of this peaceful society, despite the great diversity.

In addition to announcing ethnic tolerance, from the beginning of the existence of an independent state, Kazakhstan begins in all fields a process that can be called a fight for Kazakhization, treated as an expression of the "instinct of self-defence" of the nation regaining its rightful place (see Gawęcka-Penkala 2008). It permeates all politics and the public sphere. Kazakhstan is presented in the categories of "rebirth", strengthening, development, but at the same time the domination of values represented by the titular nation. It should also be stressed that this policy is carefully hidden in official documents and even denied its existence.

Although both the 1993 constitution of Kazakhstan and many ideological public statements emphasize the equality of all nations living in Kazakhstan, in fact, Kazakh ethnic culture is promoted in all its aspects: language, traditions, history. At the same time, multiculturalism, the cult of internationalist values, is officially emphasized, which in essence provides a peculiar, internally contradictory ideological whole. The country is officially multinational, based on the friendship of these many nations always living here, which manifests itself in the promotion of state-owned, central public events 
and in the content conveyed by the mass media. Next to this, the dominance of the value of the "indigenous" nation over the values of nations defined as stainless is marked at every step. This contradiction is to be counteracted recently by hidden or rejected facts about the glorious history of the Kazakhs and the disregarded values of life in the steppe. Thus, the language of decolonization narrative provides a tool to reconcile apology of all aspects of Kazakh culture and past and the ideology of equality of nations, living together in the Kazakh state (Sejdimbek 2012, p. 550; O’Callaghan 2004).

Nursultan Nazarbayev adjusts his ethnic policy by referring to the concept of the Eurasian economic system in which the Turkic-speaking nations have their place (Chebotarev 2015; Sejdimbek 2012, p. 550).

Final remarks: the ALZHIR museum in the national context

Within the presented ethnic and at the same time state-building narrative, the ALZHIR camp museum occupies an important place. A performative vision of the Kazakh nation and Kazakhstan has been developed within the structure and content of the museum's message. The meaning of the national museum of the women's correction camp is provided by the architecture of the whole and exhibition, building national pride, a sense of uniqueness and moral value of the Kazakh nation. The museum also serves to enhance the concept of a strong, independent nation and state. In this way, the museum - unrelated directly to the heroic history of former Kazakhstan and the Kazakh nation - could be a part of a great nation-building process, which consists of ways of expressing and experiencing national identity. It forms a common set of resources, from which individuals and groups of people can use to update and strengthen the sense of national belonging. The contents conveyed in the museum itself and in the Web space related to the museum, bring some national associations, 
inconsistent and compact patterns, from which the Kazakhs build, shape and develop their national identity. Moreover, they form the basis for epistemological and ontological ways of understanding the nation and the modes of belonging to it.

\section{References}

Bachórz A. (2009), Wielka Wojna Ojczyźniana we współczesnej rosyjskiej kinematografii. O nośnikach pamięci zbiorowej, "Przegląd Zachodni” No. 2

Bisztyga A. (2015), Terenowa administracja rzq̨dowa oraz samorząd terytorialny $w$ Republice Kazachstanu. Aspekt konstytucyjny, "Studia Iuridica Lublinensia" No. 22

Kazachstan. Spoleczeństwo, historia, polityka (2000), (Eds.) Bodio K., Wojtaszczyk A., Dom Wydawniczy ELIPSA,Warszawa

Bogumił Z., Wawrzyniak J. (2010), Narracje zniszczenia: trauma wojenna $w$ muzeach miejskich Petersburga, Warszawy i Drezana, “Kultura i społeczeństwo" No. 54(4)

Bogumił Z. (2012), Pamięć Gulagu, Wydawnictwo Universitas, Kraków Chebotarev A. (2015), Politiczieskaja mysl suwerennogo Kazachstana: dinamika idiei i ocenki, Astana-Ałmaty

Edensor T. (2004), Tożsamość narodowa, kultura popularna i życie codzienne, WUJ , Kraków

Gellner E. (1992), Dwie formy więzi spotecznej, [in:] Sytuacja mniejszościowa i tożsamość, (Eds.) Mach Z., Paluch A., WUJ, Kraków

Głowacka-Grajper M. (2016), Transmisja pamięci: działacze „sfery pamięci" i przekaz o Kresach Wschodnich we wspótczesnej Polsce, Wydawnictwa Uniwersytetu Warszawskiego, Warszawa http:// www.museum-alzhir.kz [December 2017] 
Karin E., Chebotarev A. (2002), The Policy of Kazakhization in State and Government Institutions in Kazakhstan, [in:] The Nationalities Question in Post-Soviet Kazakhstan, (Eds.) Masanov N., Karin E., Chebotarev A., Natsuko O., Institute of Developing Economies JETRO, Chiba

Masanov N. (2002), Perceptions of ethnic and all-national Identity in Kazakhstan, "The Nationalities Question in Post-Soviet Kazakhstan" No. 51

O'Callaghan L. (2004), War of Words: Language Policy in Post Independence Kazakhstan, "Nebula" No. 1(3)

Penkala-Gawęcka D. (2009), Mikropolityka etniczności. Obchody wiosennego święta Nauryz $w$ postsowieckim Kazachstanie, "Etnografia Polska", Vol. LIII

Sejdimbek A. (2012), Mir Kazachow, Foljant, Astana

Thompson E.M. (2000), Trubadurzy imperium: literatura rosyjska $i$ kolonializm, Universitas, warszawa

Wites T. (2002), Kazachstan - zmiany i wyzwania gospodarcze na przetomie XX i XXI wieku, [in:] Afryka, Azja, Ameryka Eacińska wyzwania spoleczno-gospodarcze w XXI wieku, (Ed.) Wague M., Multi-Print, Warszawa

Załęski P. (2012), Radzieckość $w$ tożsamości kulturowo-spotecznej we wspótczesnym Kirgistanie, [in:] Tożsamości narodowe na obszarze postradzieckim. Między dziedzictwem a tradycja wynaleziona, (Eds.) Załęski P., Breslavskaia E., Włodarkiewicz M. Oficyna Wydawnicza ASPRA-J R, Warszawa 